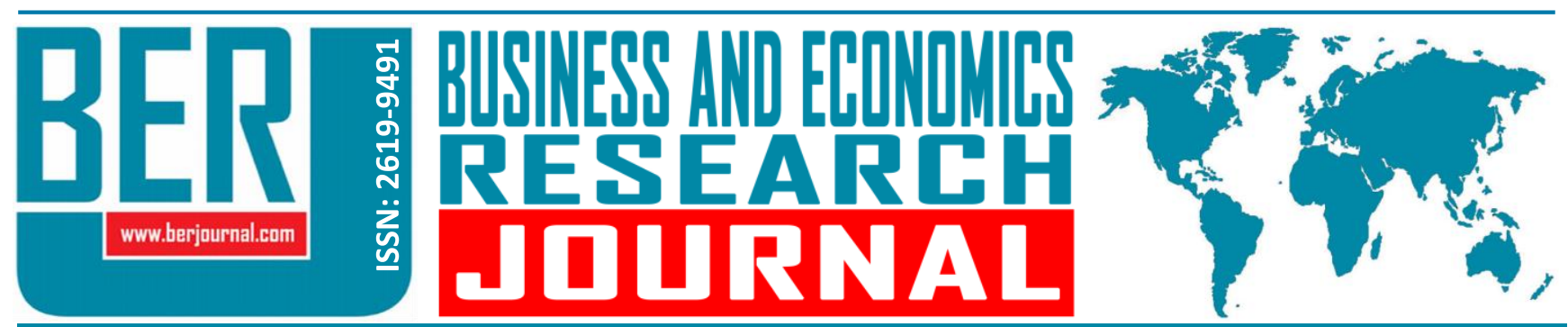

Business and Economics Research Journal Vol. 10, No. 5, 2019, pp. 1155-1166 doi: 10.20409/berj.2019.227

\section{Orta Düzey Yönetim/Yönetici Üzerine Bir Literatür Araştırması}

\section{Sukran Gokce ${ }^{\mathrm{a}}$}

Öz: Bu çalışmanın amacı, orta düzey yönetim/yönetici kimliğini ve bu yönetim düzeyinin örgütteki rollerini ortaya koyarak literatüre katkı sağlamaktır. Ayrıca stratejinin belirlenmesi ve uygulanması sürecine orta düzey yönetimin katılımı ve bunun performans üzerindeki olumlu sonuçlarına dair daha derin bir anlayış geliştirmeyi amaçlamaktadır. Bu doğrultuda, "orta düzey yönetim/yönetici" ve "orta düzey yöneticilerin rolleri" ile stratejik yönetim bağlamında bu konuyu ele alan, Google ve akademik veri tabanındaki dergiler üzerinden 1975-2017 yılları arasında yayınlanmış olup, ulaşılabilen ulusal ve uluslararası çalışmaların genel bir değerlendirilmesi yapılmıştır. Öncelikle bu konuda yapılan ulusal çalışmaların uluslararası çalışmalara göre azlığı dikkat çekmektedir. Araştırma sonuçlarına göre tüm yazarlar, orta düzey yönetimin üst düzey ile alt düzey yönetim arasında bulunan geniş bir yönetim grubu olduğu konusunda hemfikirdir. Ayrıca, orta düzey yönetim/yöneticiler diğer düzeylerden işlev, organizasyon yapısı ve araştırmacıların eğilimi olmak üzere üç noktada farklılaşmaya gider. Orta düzey yönetim/yöneticilerin rolleri arasında önemli düzeyde örtüşme vardır ve rollerin kapsamı örgütsel bağlam, zaman ve yöneticilerin tutumuna bağlı olarak şekillenmektedir. Araştırmacılar söz konusu yöneticilerin özellikle iletişim ve işbirliği rolüne vurgu yaparken, karar verme rolünü göz ardı etmişlerdir.

\section{A literature Review on Middle Management/Manager}

Abstract: The aim of this study is to contribute to the literature by revealing the middle level management/manager identity and the role of this management level in the organization. It also aims to develop a deeper understanding of the involvement of mid-level management in the process of identification and implementation of strategy and its positive results on performance. In this respect "middle level management/manager" and "roles of middle level managers" and in the context of strategic management and published in the journals in the Google and academic database between 1975-2017 and an overall evaluation of national and International studies was made. First of all, the lack of national studies on this subject is remarkable compared to International Studies. According to the results of the research, all authors agree that mid-level management is a large management group that exists between senior and senior management. In addition, mid-level management/managers differ from other levels at three points: function, organizational structure and the tendency of researchers. Mid-level management/managers have significant overlap between roles and the scope of roles is shaped by organizational context, time and the attitude of managers. Researchers have ignored the role of decision making, especially when emphasizing the role of communication and collaboration of these managers.
Anahtar Sözcükler: Orta Düzey Yönetim, Orta Düzey Yönetici, Rol, Stratejik Yönetim

JEL: M10, L25, M12, M15, D04

$\begin{array}{ll}\text { Geliş } & : 18 \text { Mart } 2019 \\ \text { Düzeltme } & : 08 \text { Mayıs } 2019 \\ \text { Kabul } & : 15 \text { Mayıs } 2019 \\ \text { Tür } & : \text { Derleme }\end{array}$

Keywords: Middle Management, Middle Manager, Role, Strategic Management

JEL: M10, L25, M12, M15, D04

$\begin{array}{ll}\text { Received } & : 18 \text { March } 2019 \\ \text { Revised } & : 08 \text { May } 2019 \\ \text { Accepted } & : \text { 15 May } 2019 \\ & \\ \text { Type } & \text { : Review }\end{array}$




\section{Giriş}

Bir organizasyonda örgütsel hedeflere ulaşmak için farklı yönetim düzeyleri farklı güç, otorite ve sorumluluk derecelerine sahiptirler. Bu kurumlardaki yetki ve sorumluluk doğrudan yönetim düzeyinin açık ve net tanımına bağlıdır. Geleneksel yönetim anlayışında; üst düzey yönetim/yöneticiler örgütün nihai sorumlusu olarak geleceğe yönelik amaç ve hedeflerin belirlenmesinden, orta düzey yönetim/yöneticiler bu amaç ve hedefleri gerçekleştirmek için plan ve eylemlerin koordine edilmesinden, alt düzey yönetim/yöneticiler ise günlük faaliyetlerin yerine getirilmesi için yönetsel işlevleri olmayan iş görenleri yönetmekten sorumlu tutulmaktadırlar. Ancak belirsizliği ve karmaşıkığı giderek artan bir çevrede faaliyet gösteren günümüz örgütlerinde üst düzey yöneticiler işgal ettikleri konum sebebiyle çoğu zaman olaylara uzak ve yetersiz kalabilmektedir. Bu nedenle etkin bir örgüt yönetiminde organizasyon içerisinde pek çok görevi yerine getiren orta düzey yönetim/yöneticilerini tanımlamak ve temel rollerini ortaya koymak önemlidir. Ayrıca örgütlerde stratejilerin başarılı bir şekilde uygulanması noktasında orta düzey yöneticilerin bu sürece katılımı ve bu yolla örgüt performansının artırılması esastır.

Günümüzde pek çok yazar artan sorunlarla baş etmede orta düzey yöneticilerin önemine vurgu yapmakta (Tregoe ve Tobia, 1990; Wooldridge ve Floyd, 1990; 1992; Wooldridge, Schmidt ve Floyd, 2008; Yang vd., 2010) ve yönetimin etkinliğini değişen iç ve dış çevre şartlarını gözeten, yorumlayan, kurum kabiliyetlerini yeniden şekillendiren, değişim sürecinin ayrılmaz parçası olan orta düzey yöneticilere dayandırmaktadır (Wooldridge ve Floyd; 1992: 36). Bu çalışma, orta düzey yöneticilerin tanımı, rolleri ve bu yöneticilerin stratejik sürece nasıl katkıda bulunduğuna dair anlayışımızı geliştirmek gibi bir yaklaşımı benimsemektedir. Orta düzey yöneticilerin stratejik değişimin ortaya konmasında gerek formülasyon gerekse uygulama sürecine dair katkılarının neler olduğu ve bu katkıların nihai olarak performansa nasıl yansıdığı ele alınan araştırma sonuçlarına göre değerlendirilecektir.

\section{Orta Düzey Yönetim/Yönetici Kimdir?}

Birçok araştırmacı örgütlerin değişimi, gelişimi ve sağlığı açısından aşağıdan yukarıya doğru bilgi akışının önemine vurgu yapmaktadır (Argyris ve Schön, 1978; Glauser, 1984; Dutton ve Ashford, 1993; Floyd ve Wooldridge, 1996). Geleneksel düşünme biçimi, strateji geliştirme ve uygulama faaliyetlerini üst yönetimin sorumluluğunda adleder ve orta düzey yöneticileri "üst yönetimin tanımladığı değişikliklerin uygulayıcıları" (O'Shannassy, 2003: 55) olarak tanımlar. Ancak günümüzde insiyatif almak ve öngörüyle hareket ederek kararlara katılmak orta düzey yöneticilerin işlerinin bir parçası haline gelmektedir (Song ve Olshfski, 2008; Wooldridge vd., 2008). Bir başka ifade ile orta düzey yöneticilerin pasif bilgi sağlayıcıları rolünden çıkarak karar mekanizmalarında aktif rol oynadıkları ve farklı bakış açılarının alınan kararlar üzerinde etkinliği artırdığı kabul edilmektedir (Nemeth, 1997: 63). Örgütte bilgi akışının merkezinde yer alan orta düzey yöneticiler, bu bilgileri eleştirel anlamda inceleyerek, filtreleyerek, yorumlayarak ve bazen aktörlerin fikir birliğine varmalarına yardımcı olarak stratejik açıdan liderliğe daha fazla erişmektedir (Nonaka ve Takeuchi, 1995: 87).

Stoner ve Freeman (1992) orta düzey yöneticileri, örgüt hiyerarşisinde ortalarda yer alan ve bir kısım yöneticileri yönetme görevini üstlenirken diğer yandan bazı çalışanların yapmış oldukları işlerden sorumlu tutulan yöneticiler şeklinde tarif ederler. Dolayısıyla bu kademeyi üst düzey yöneticilerin altında ve hiyerarşide birinci düzey denetimin üstünde yer alan örgüt kademesi olarak tanımlamak mümkündür (Dutton ve Ashford, 1993: 398). Bir başka ifade ile orta düzey yöneticiler "kurumsal hiyerarşinin orta seviyesindeki belirli bir iş biriminden sorumlu bireyler"; orta düzey yönetim ise örgüt hiyerarşisinde "işletim merkeziyle tepe yönetimi arasında" yer alan bir konum olarak tanımlanmaktadır (Mintzberg, 1979: 98). Bu yöneticiler, üst düzey yönetim stratejilerinin uygulanmasından sorumlu olmakla birlikte alt düzey çalışanlar üzerinde denetim yetkisine sahiptirler. Bir uygulayıcı olarak, operasyonel seviyedeki çalışanlara rehberlik etmektedirler. Dolayısıyla orta düzey yöneticilerin hem üst hem alt hem de orta kademelere eş zamanlı olarak hizmet etmeleri gerekmektedir (Joseph ve Winston, 2005: 12). Çoğu organizasyonda en geniş yönetici grubunun bulunduğu kademedir (Griffin, 1997: 9). Ayrıca "orta" sınırının çok sayıda yönetim seviyesine yayılmış olması nedeniyle "orta" tanımı üzerindeki uzlaşma eksikliği öz kimlik sorununu ortaya çıkarmaktadır. Bu nedenle orta düzey yönetim yapısı her bir örgütün kendi yapısına bağlı olarak şekillenmektedir. Bununla birlikte orta yönetim düzeyinin diğer yönetim düzeylerinden temel farkı üst yönetim bilgisi ile operasyon 
bilgisini birleştirmiş olmasıdır. Örgüt stratejisi ile günlük (operasyonel) faaliyetler arasında arabuluculuk yapmalarını sağlayanda bu kombinasyondur (Nonaka, 1994: 19).

Likert'e (1961) göre, orta düzey yöneticiler üst yönetim ile alt yönetim seviyeleri arasındaki “bağlantı pimleri"dir. Bu nedenle, üst yönetim ekibinin bir üyesi ve örgütsel birim temsilcileri olarak orta düzey yöneticiler ortaya konacak olan eylemlerde başlangıç noktası olarak görev yaparlar (Nonaka, 1988: 11). Dolayısıyla eylemin sonuçları üzerinde olumlu ya da olumsuz doğrudan bir etkiye sahiptirler. Çeşitli kaynaklardan elde edilen bilgileri sentezler, değerlendirir ve stratejik etkileşimlere göre gerekli önlemleri almak için üst yönetime aktarırlar. Süreç içerisinde değişen stratejik niyetlere kendi yorumlarını da ekleyerek, uyarlamada dikkate alınması gereken birçok alternatifi üst yönetime sunarlar (Boyett ve Currie, 2004: 51). Bu yolla orta düzey yönetim ve yöneticileri üst yönetimin olayları algılama biçimi üzerinde güçlü bir etkiye sahiptirler.

Orta düzey yönetim/yöneticiyi diğer yönetim düzeyleriyle kıyaslayarak tanımlama yoluna gittiğimizde burada kullanılan ilk ölçüt, kurumdaki işlevleridir. Orta düzey yönetim, örgütün operasyonel merkezinde yer alır ve bu yöneticiler için hem kuramsal hem de teknik beceriler eşit derecede önemlidir. Beşeri yetenekler bakımından ise yönetim kademeleri arasında fark yoktur ve bu yeteneklere aynı düzeyde sahip olmaları ve kullanmaları beklenir (Bingöl, 1998: 256). Ayrıca yapılan uygulamaların denetlenmesi, elde edilen sonuçların ölçülmesi ve hedeflere ulaşılma derecesinin değerlendirilmesi gibi önemli işlevleri de bu başlık altında ifade edilebilir. Organizasyon yapısı veya içeriği, orta düzey yönetimi diğer yönetim düzeylerinden ayırmak için kullanılan bir diğer ölçüttür. Orta düzey yöneticilerin yapısal konumlarına baktığımızda "başkalarını etkileme yetenekleri" ve "örgütün günlük çabalarını yönetme" sorumluluğu açısından önemi vurgulanmaktadır. Ayrıca sahip oldukları pozisyon nedeniyle operasyonel etkinliklere, çalışanların beceri kümelerine ve genel pazar dinamiğine daha aşina oldukları ifade edilebilir. Bu durum söz konusu yöneticilere stratejik niyetlerin piyasa eğilimleri ve iç yetenekler doğrultusunda değerlendirilerek üst yönetime stratejik yön konusunda tavsiyede bulunma ve strateji uygulamasına yönelik olası engelleri belirleme noktasında üstünlük sağlamaktadır. Örgüt içerisindeki konumu itibariyle üst düzey yöneticiler ve alt düzey personel arasında aracı rolü görerek örgüt içerisindeki eylemi, belirlenen stratejik yön doğrultusunda yönlendirme ve etkileme fırsatına sahiptirler. Ayrıca orta düzey yöneticiler diğer çalışanlarla üst düzey yöneticilerin iletişiminin sağlanmasında etkin rol oynamaktadır. Bu anlamda kritik arabuluculardır. Orta düzey yönetimi diğer yönetim düzeylerinden ayırmada kullanılan son ölçüt ise araştırmacıların bu konudaki eğilimleri olarak ifade edilmektedir. Bu eğilimler temelde iki başlık altında ele alınmaktadır. illki orta düzey yönetim/yöneticilerin stratejik rolleri diğeri ise değişim yönetimindeki önemli katkıları üzerinedir.

\subsection{Orta Düzey Yönetim/Yöneticinin Stratejik Rolleri}

1990 'lı yıllar ve sonrasında üst yönetimin stratejik planlarını dinleyerek, bu planların iletilmesi ve uygulanmasını denetleyen orta düzey yönetim ile ilgili geleneksel görüş yavaş yavaş geçerliliğini yitirmeye başlamıştır (Hancock ve Hellawell, 2003: 10). Günümüzde değişimle başa çıkmaya çalışan orta düzey yöneticiler üst düzey perspektifler ile alt düzey uygulamaları uzlaştırmakla ilgilenmektedir. Bu paralel de King, Fowler ve Zeithaml (2001; 95) orta düzey yöneticiliği "işletmenin beynindeki sinapslar" olarak tanımlarlar. Rolün bu şekilde anlaşıması, orta düzey yöneticilerin yoğun bilgi transferi için gerekli bağları beslediği "paylaşılan bir örgütsel kimlik duygusu" yaratmak üzere üst düzey yöneticilerle birlikte çalışması olarak açıklanmaktadır (Kanter, 1983). Literatüre baktığımızda orta düzey yöneticiler ile strateji arasındaki ilişkinin varlığına dair en sistematik ve kapsamlı çalışmalar Floyd ve Wooldridge $(1990,1992,1997)$ tarafından yapılmıştır. Yazarlar orta düzey yöneticinin rolünü, organizasyonel eylemi üst yönetimin stratejik niyeti ile uyumlu hale getiren yönetsel müdahaleler şeklinde tanımlamaktadırlar. Söz konusu yöneticiler kurumsal stratejiyi eylem planlarına ve bireysel hedeflere dönüştürerek strateji uygulama yoluyla bu rollerini gerçekleştirirler (Currie ve Procter, 2005: 1327).

Örgütsel bağlantı yerleri olarak orta düzey yöneticiler stratejik bilgi ile teknik bilgiyi birleştirmek için benzersiz şekilde konumlandırılırlar (Nonaka, 1988; 15). Sahip oldukları bu benzersiz konum orta düzey yöneticilere bazı stratejik roller yükler; bu roller şampiyonluk, sentezleme, kolaylaştırma ve uygulama konularını kapsamaktadır. Şampiyonluk rolünde, orta düzey yöneticiler üst yönetime yenilikçi fikirler ve iş 
fırsatları sunarlar. Stratejik seçeneklerin üst yönetime kalıcı ve ikna edici bir şekilde aktarımı olarak tanımlanan şampiyonluk görevi, stratejide önemli bir orta düzey yönetim işlevi olarak görülmektedir (Floyd ve Wooldridge, 1992; 154). Orta düzey yöneticiler tarafından üst yönetime sunulan tüm fikirler stratejik öneriler değildir. Aynı zamanda iç ve dış çevreden gelen bilgileri değerlendirme, öznel yorumlama yoluyla tavsiye niteliğinde üst yönetime sunarlar (Ranson, Hinings ve Greenwood, 1980: 410). Örneğin orta düzey yöneticiler 'tehdit' ve 'fırsat' kategorilerini kendilerine göre belirleyerek, konuların nasıl algılanacağı ve yorumlanacağını etkilerler (Dutton ve Jackson, 1987: 81). Bu nedenle, bilginin yorumlanması ve değerlendirilmesi olarak tanımlanan sentezleme üst yönetim algılarını etkileyerek stratejik bir girişimin önünü açma noktasında öncü olabilir (Floyd ve Wooldridge, 1992: 155). Bu yol orta düzey yöneticilerin strateji oluşumunu yukarı doğru etkilediği ikinci yoldur. Kolaylaştırıcı rolde, orta düzey yöneticiler farklı uyum stratejilerini ve değişimleri beslerler (Floyd ve Wooldridge, 1992: 156). Bu yolla örgütsel düzenlemeleri daha esnek hale getirirken iş gücü arasında bilgi paylaşımını arttırmakta (Mintzberg, 1979: 64) ve örgüt üyelerini değişen koşulları öngörmeye, yeni yaklaşımlar deneyimleyerek bunları uygun şekilde adapte etmeye teşvik ederek öğrenmeyi kolaylaştırmaktadır (Chakravarthy, 1982: 37). Bilgi paylaşımı ve öğrenmeyi teşvik eden bu yöneticiler astlarının değişimle başa çıkma yeteneklerini arttıırlar. Üst yönetim stratejisinin uygulanması genellikle orta düzey yöneticilerin temel stratejik rolü olarak kabul edilmektedir (Nutt, 1987; 5) ve amaç, istenen sonuçlara göre performansı kontrol etmektir (Hrebiniak ve Joyce, 1984: 37). Örgütsel eylemi stratejik amaçlarla uyumlaştırma ve yönetimsel müdahaleler olarak tanımlanan uygulama, orta düzey yönetimin dördüncü stratejik işlevidir.

Rezvani (2017) ise yaptığı çalışmada orta düzey yöneticilerin rollerini beş başlık altında toplamaktadır. Bunlar, stratejik, yönetsel, karar verme, liderlik, iletişim ve işbirliği ile ilgili rollerdir. Araştırmacılar stratejik ve iletişim-işbirliği rollerine daha çok odaklanırken diğer rolleri özellikle orta düzey yönetimin karar verme rolünü göz ardı etmişlerdir. Oysa orta düzey yöneticiler tarafından sahip olunan bilgi farklı olduğundan, kararların içeriğinde yer almaları durumunda alınan kararların kalitesi daha yüksek olacaktır (Martin ve Eisenhardt, 2010: 269). Araştırma bulguları kararlara katılma ve kaynak tahsisi gibi konularda söz sahibi haline gelen orta düzey yöneticilerin motivasyon ve örgütsel hedefleri sahiplenme hissi; çatışmaların üstesinden gelme yeteneğini artırırken (Westley, 1990: 339) örgüte yabancılaşma hissini azalttığını ortaya koymuştur (Jarzabkowski ve Balogun, 2009: 1257). Ayrıca özgür karar alma süreçleri sayesinde daha verimli hizmet üretimi ve sunumuna ulaştıkları; risk alma, yenilikçi ve proaktif adımların şekillendirdiği girişimci eğilimlerin daha rahat ortaya çıktığı kabul edilmektedir (Dennis, Langley ve Rouleau, 2005: 262).

Bu alanda öncü çalışmalardan biri olan "Strategy Implementation Versus Middle Management SelfInterest" adlı eserlerinde Guth ve MacMillan (1986), orta düzey yöneticilerin seçilen stratejinin sonucunu çabalarıyla etkilemede büyük ölçüde başarılı olduklarını ifade etmektedir. Aksine orta düzey yönetici strateji geliştirme sürecinden dışlandığında, yöneticinin stratejiye bağlıı̆̆ı daha az olacaktır. Bu, uygulamanın da daha az başarılı olmasına neden olacaktır. Bu senaryoda orta düzey yöneticilerin yaratıcılık ve akılcı yetkinlikleri kullanılmaz, desteklenmez ve terfi ettirilmez. Bu nedenle, orta düzey yöneticiler beklenmedik durumlara tepki gösteremezler, sadece yukarıdan formüle edilen stratejiye güvenirler. Bu tezi destekler nitelikte bir diğer çalışmada Beer ve Eisentat (2000) formüle edilen stratejilerin başarılı bir şekilde uygulamaya aktarılamamasının önündeki önemli engellerden biri olarak orta düzey yöneticilerin hedeflere olan bağlııkları ve temel yeteneklerinin göz ardı edilmesini gösterir ve bu sorunun ancak orta düzey yöneticilerin stratejik rollerinin geliştirilmesiyle çözüme kavuşturulabileceğini ifade ederler.

\subsection{Orta Düzey Yönetim/Yöneticilerin Değişim Yönetimine Katkısı}

Değişim "bir bütünün ögelerinde ve bu ögelerin birbirleriyle ilişkilerinde, öncekine göre nicelik ve nitelikçe gözlenebilir bir ayrılığın oluşması veya belli bir durum esas alınmak koşuluyla, söz konusu durumda meydana gelen farklılaşma" (Tezcan, 1980; 28) ya da kişilerin veya nesnelerin yerlerinin değişmesi; kişisel bilgi, beceri ve yeteneklerin başlangıçtaki durumundan farklı bir konuma getirilmesi şeklinde de tanımlanmaktadır (Koçel, 2011: 668). Çevresindeki değişikliklere karşı duyarlı olma ve iş yapma biçimlerini buna göre güncellemek durumunda olan örgütlerin, değişimi gereği gibi karşılayamaması ve durağan kalması, çözülmeye ve nihayetinde örgütsel ölüme yol açmaktadır. Dolayısıyla, değişimin nasıl başarılacağı, yani 
değişim sürecinin nasıl yönetileceği örgütün uzun vadede yaşamını sürdürmesi ve başarılı olması için öncelikli bir konu haline gelmektedir (Akyüz, 2006; 7).

Sürekli değişen bir çevrede faaliyet gösteren günümüz örgütlerinin en temel sorunlarından birisi değişime uyum sağlamaktır. Değişim yönetimi; bu uyumun bilinçli, planlı ve yöntemli bir biçimde gerçekleştirilme sürecidir. Bu sürece dolayısıyla bu uyuma orta düzey yöneticilerin katkısı esastır. Heyden vd. (2017) 450'den fazla küresel işletmenin üst ve orta düzey yöneticilerinden elde ettiği veri setini kullanarak, üst ve astların örgütsel değişim sürecinde rollerini en iyi şekilde nasıl kullanacakları ve bu dinamiği nasıl destekleyeceklerini araştırmıştır. Araştırma sonuçları, orta düzey yöneticiler tarafından başlatılan değişim girişimlerinin genellikle daha iyi seviyede çalışan desteği gördüğü dolayısıyla bu sürece güçlü bir bağlılık gösterildiğini ortaya koymaktadır. Öncelikle orta düzey yöneticiler örgüt içindeki ara konumlarından dolayı bağlantısız aktörler ve alanlar (Floyd ve Wooldridge, 1999) arasında ara yüz görevi görürler. Dolayısıyla bu yöneticiler büyük sistemde var olan çelişkileri ve tutarsızıkları çözmek için bu ara yüzleri sürekli düzenleyip yeniden yapılandıran oyuncular haline gelmektedir. Bu oyuncuların insiyatifleri olmaksızın örgütün eylemlerini etkin bir şekilde yerine getirmesi oldukça güçtür. Belli bir uzmanlık ve bilgi alanına sahip orta düzey yöneticiler bir yandan örgüt içi değişimi kolaylaştırırken diğer yandan değişime cevap verme hızını artırarak örgütlerde değişim yönetiminin temel unsurları haline gelmektedir. Çünkü sahip oldukları konum itibariyle başarılı örgütsel değişimin gereklerini tüm açılardan (alt-üst-eşit düzey) görebilme fırsatına sahiptirler (Kanter, 1982: 98).

Yerleşmiş pek çok bireysel ve örgütsel alışkanlıkları değiştirdiği için sancılı bir süreç olan değişim; az ya da çok her zaman bir dirençle karşılaşır. Örgütsel değişimin başarısı büyük ölçüde, değişime olan bu direncin azaltılması ya da tamamen ortadan kaldırılmasıyla yakından ilişkilidir. Örgütsel değişim sürecinde ortaya çıkabilecek direnci asgari düzeye indirebilmek için değişime hazırlık yapılması gerekir. Bu bağlamda çalışanlar değişime hazırlanmalı ve direnç alanları ya da konuları tespit edilerek gerekli tedbirler alınmalıdır. Çalışanların kurumlarındaki değişimlere yönelik algıları, değişime gösterecekleri tepkiyi etkilemekte, dolayısıyla örgütsel değişimin başarısında belirleyici bir rol oynamaktadır. Orta düzey yöneticiler sahip oldukları konum ve görevleri itibariyle gerek üst yönetim gerekse çalışanların değişime yönelik algılarını yönlendirmek ve yönetmek suretiyle değişimin başarıyla uygulanmasını sağlayabilirler. Ayrıca sadece örgüt içi değil aynı zamanda müşteriler, tedarikçiler ve diğer dış paydaşlar ile ilişkileri yönetme sorumlulukları da vardır. Tüm bu iletişim ve etkileşimler orta düzey yöneticilerin değişim yönetiminde ilişki yöneticileri (Floyd ve Wooldridge, 1997: 469) olarak tanımlanmasına yol açmaktadır. Birçok nitel çalışma orta düzey yöneticilerin örgütleri daha esnek hale getirdiği ve resmi beklentiden uzaklaşan davranışları teşvik ederek informal bilgi paylaşımını artırdığını ortaya koymaktadır (Bower, 1970; Kanter, 1983; Mintzberg, 1979).

\section{Orta Düzey Yönetim/Yöneticilerin Örgüt Performansına Katkısı}

Örgütün kaynaklarını etkin ve verimli bir şekilde kullanarak amaçlarına ulaşabilme yeteneği olarak tanımlanan performans (Daft, 2000) tüm örgütlerin nihai hedefidir. Araştırmalar orta düzey yöneticilerin, bir organizasyonun yetenekleri ile finansal performansı arasındaki ilişkileri çevreleyen nedensel belirsizliklere nüfuz etme olasılı̆ıının üst düzey yöneticilerden daha yüksek olduğunu ortaya koymaktadır (King vd., 2001). Çünkü bu yöneticiler kritik ve emtia yetenekler arasındaki farkı tanırlar. Emtia yeteneklerinin verimliliğini arttırmak ve başarı için kritik olan yeteneklerin etkinliğine yoğunlaşmak gerektiğini bilirler. Bir başka araştırma sonucu ise orta düzey yöneticinin örgütteki geçmişinin, performansla önemli ölçüde ilişkili olduğudur (Mair, 2005: 266). Çünkü orta düzey yöneticiler zamanla sorunları daha iyi algılayıp, çözümlemeleri üzerinde daha etkin sonuçlara ulaşmaktadırlar. Orta düzey yöneticilerin performansa olan katkısını belirlemede diğer bir önemli noktada üst yönetim desteği ve örgüt kültürü başta olmak üzere sahip olunan organizasyonel özelliklerdir. Üst düzey yönetim desteğini inceleyen çalışmalar, orta düzey yönetimin üst düzey yönetimi açık fikirli ve destekleyici olarak algıladıklarında bir kuruluştaki alt düzey çalışanların satış yapma olasılığııın daha yüksek olacağını ortaya koymaktadır (Schilit ve Locke, 1982: 315). Bu tez, bir örgütün üst düzey yöneticileri tarafından kullanılan liderlik tarzının, aynı örgütün orta düzey yöneticilerinin sorunları nasıl ele aldığını önemli ölçüde etkilediğini ortaya koyan farklı bir çalışmada da desteklenmiştir (Ansari ve Kapoor, 1987). 
Performansın organizasyonun orta düzeyinde olanlardan büyük ölçüde etkilendiğini savunan Wooldridge ve Floyd (1990), Floyd ve Lane (2000), Currie ve Procter (2005) ve Rouleau (2005) orta düzey yöneticileri örgütlerde birçok role sahip stratejik aktörler olarak tanımlamaktadırlar. Çünkü orta düzey yöneticilerin üst düzey yöneticilere kıyasla müşterilere ve pazara daha yakın olması (Dutton vd., 1997), müşterilerden gelen zayıf sinyalleri daha kısa sürede saptamasını sağlarken, stratejik fırsatları fark etmesine neden olacaktır. Tüm bunlar çevreye uyarlanabilirliği artıracağından endüstrideki en son gelişmeler ışığında dinamik bir ortamda örgütün rakiplerinden daha iyi bir performans sergilemesine yol açacaktır. Bir başka ifade ile işletmenin temel yeteneklerinin geliştirilmesi ve sürdürülmesindeki önemli rolünün yanı sıra örgütün temel yeteneği ile rekabet avantajı bağlantısını kuracak olan da yine bu stratejik aktörlerdir (Kanter, 1982).

Yukarıda ifade etmeye çalıştığımız orta düzey yönetim/yönetici tanımı, rolleri ve stratejik yönetim sürecine olan etkisine dair 1975-2017 yılları arasında yapılan çalışmalardan çıkarılan önemli notlar şu şekilde ifade edilebilir:

Harari ve Zeira (1977) çok uluslu bir işletmenin planlı değişim sürecini ele aldıkları çalışmalarında uygulama çabalarının belirleyici unsurunun, orta düzey yöneticilerin menfaatleri ile örgütsel menfaatler arasındaki hedeflerin tutarlılı̆ı olduğunu ortaya koymaktadırlar. Yazarlar bu tutarlıı̆ı̆ örgütte bir güven ortamı yarattığını, bu güveninde stratejik değişimin yarattığı belirsizlikleri gidermek açısından kritik olduğunu ifade etmektedirler.

Guth ve MacMillan'ın (1986) çalışması orta düzey yöneticilerin uygulama çabalarıyla ilgili öncü çalışmalardandır. Bu araştırma, orta düzey yöneticilerin üst yönetim tarafından belirlenen stratejik değişime bağlılık düzeyinin uygulama sonuçları üzerindeki etkisine dair bulgular içermektedir. Nitel veriler kullanılarak yapılan bu çalışmada, orta düzey yöneticilerin seçilen stratejinin sonucunu çabalarıyla etkilemede büyük ölçüde başarılı oldukları gözlemlenmiştir.

Schilit'in (1987) çalışması orta düzey yöneticilerin stratejik etkilerini büyük bir örneklemde inceleyen ilk araştırmalardan biridir. Yazarın bulduğu sonuçlar bu anlamda cesaret vericidir. Orta düzey yönetimin/yöneticilerin stratejiyi etkileme girişimlerinin genellikle başarılı olduğunu ve gösterecekleri çaba ve gayretin başarılı bir uygulama için şart olduğunu ifade etmektedir.

Nutt (1987) orta düzey yöneticilerin strateji geliştirme sürecine dâhil edildikleri durumlarda stratejik değişim çabalarının başarı düzeyinin arttığından bahseder.

Westley (1990) orta düzey yöneticileri, örgütün üst düzey yöneticileri tarafından verilen kararların uygulayıcıları ve bilgi tedarikçileri olarak tanımlar. Bu nedenle bu grup yöneticiler, üretim, kalite kontrolü, satış ve araştırma-geliştirme gibi strateji iş birimi içerisinde "ikinci düzey" yürütme işlevlerini yerine getirmekle görevlidirler.

Floyd ve Wooldridge $(1990,1992,1996)$ yaptıkları ilk çalışmalarda, orta düzey yönetim rollerini tanımlayarak, bu roller ile örgütsel performans arasında güçlü bir ilişkinin varlığından bahsederler. Örgütsel yetenek geliştirmede orta düzey yönetim davranışını araştıran yazarlar bu yöneticileri üst düzey yöneticilerin direktiflerini uygulamaktan öte bilgi alanlarını, sosyal ağları ve kaynakları oluşturan ve bütünleştiren kilit aktörler olarak tanımlamaktadırlar. Daha sonraki çalışmalarında yazarlar bir adım daha ileri giderek orta düzey yöneticileri yenilikçi fikirlerin potansiyel jeneratörleri olarak tanımlamakla birlikte, dış çevre ile örgüt sınırında yer alan bu yöneticileri, strateji geliştirme ve uygulama süreçlerinin ayrılmaz bir parçası olarak görmektedirler. Gerçekten de üst kademelerin hissedar ve yönetim kurulu üyelerinin istekleri ile ilgilendiği örgütlerde, orta düzey yöneticiler, müşteri ara yüzünde ortaya çıkan eğilimlerle temasa geçmek için ideal bir konuma sahiptirler. Müşterilerden gelen taleplerin değerlendirilerek işletmenin strateji sürecine yansıtılması bu yolla orta düzey yöneticilerin strateji sürecine dâhil olmasının örgütsel performansı artırdığı ifade edilmektedir.

Judge ve Stahl (1995) orta düzey yöneticilerin sahip olduğu kişisel özelliklerin uygulama çabasının en önemli belirleyicisi olduğu ifade etmişlerdir. Bir başka ifade ile orta düzey yöneticilerin kişisel hedefleri ile stratejik değişim programının hedefleri arasında algılanan tutarlıık önemlidir. Ayrıca kurum kültürü ve ulusal 
kültürün orta düzey yöneticilerin kişisel özellikleri ile stratejik değişime ilişkin algıları arasındaki tutarlılığı önemli ölçüde modere ettiği görülmüştür.

Brower ve Abolafia (1995) orta düzey yöneticilerin stratejinin belirlenmesi, süreç yada sonuçlar üzerinde herhangi bir anlaşmazlığa düşüldüğünde yahut kendi çıkarlarını tehlikede gördüklerinde stratejiyi engelleme veya geciktirme eğilimi gösterdiklerini ifade etmişlerdir. Bu direniş örgüt performansını da doğrudan etkilemektedir.

Mc Conville ve Holden (1999) orta düzey yöneticilerin, üst düzey yöneticiler ve çalışanlar arasında bir tampon görevi gördüğünü ve belirsiz konumlarının rol çatışması kaynağı olabileceği sebebiyle onları tedirginlik ve hassasiyete maruz bırakabileceğini ifade etmektedir.

Balogun (2003), algılayıcı faaliyetler için informal iletişim süreçlerinin öneminden bahsetmektedir, ancak iletişim uygulamaları hakkında herhangi bir ayrıntıya girmemektedir. Orta düzey yöneticilerin değişim sürecindeki rolüne odaklanan gerçek zamanlı, uzun-süreli ve yorumlayıcı bir çalışma yürüten yazar yirmi altı orta düzey yönetici ile on ay boyunca yaptığı gözden geçirme toplantıları, mülakatlar, odak grupları ve belgeler yoluyla veriler sağlamıştır. Çalışma sonuçları orta kademe yöneticilerinin dört değişim-uygulama rolünü tanımladı: kişisel değişimin üstlenilmesi, değişimle başkalarına yardım edilmesi, işin devam ettirilmesi ve departmanlarda değişikliklerin uygulanması. Çalışmanın önemli bir katkısı, söz konusu ilk iki rolün öneminin tanımlanması, kişisel değişimin üstlenilmesi ve başkalarına değişim yoluyla yardım edilmesidir. "Geleneksel yönetim ve koordinasyon rolü ile tutarlı" olan diğer iki rol ile kıyaslandığında, ilk ikisi "orta yönetici görevinin önemli bir yönünü içermelerine rağmen gözden kaçmış gibi gözüküyorlar - değişim amacının somutlaştırılması" hem kendileri hem de takımları için eylemler"(Balogun 2003).

Rouleau (2005) çalışmasında orta düzey yöneticilerin günlük faaliyetleri ile örgütsel ara yüzdeki stratejik değişimi nasıl yorumladıkları ve diğerlerine bu değişikliği nasıl kabul ettirdiklerini pratikte göstermiştir. Bunu yaparken yazar iki kavram üzerinden gider. Anlam katma ve akıl yürütme. Bu kavramlar madalyonun iki farklı yüzü gibidir. Biri diğerini ima eder, onsuz var olamaz. Anlam katma, ilişkisel bir bağlamda gerçekleşir ve yöneticilerin diğerlerini nasıl etkilediklerine odaklanır. Bireysel anlam katmaların çoklu eylemlerini iç içe ve karşııklı olarak pekiştirmek örgütsel anlam katmanın süreç ve sonuçlarını şekillendirecektir. Böylelikle değişim hakkında ortak bir anlayış gelişecektir. Orta düzey yöneticilerin görevlerini layıkıyla yapmalarını sağlamak için operasyon bağlamında sosyalleşmenin önemini vurgularken, orta düzey yöneticilerin yönlendirmek istedikleri kişilerle ilişki kurma ve ilgilenme yetenekleri olduğunu kabul eder ve stratejinin öğretilmesinde daha az analitik ama daha çok söylemsel bir yaklaşımı önerir. Akıl yürütme ise, değişim hakkındaki düşüncelerini başkalarına aktarma ve onların desteğini alarak örgütsel sonuçları etkilemeleri ile ilgilidir.

Delmestri ve Walgenbach (2005) orta düzey yöneticileri çalışanların duygusal durumlarını ve algılarını yönetmek suretiyle radikal değişimlerin başarıyla uygulanmasını sağlayan uzmanlaşmış sorun çözücüler olarak tanımlamaktadır. Ayrıca orta düzey yöneticilerin rollerindeki farklılıklar ve görevlerini yerine getirirken kullandıkları bilgi türlerinden bahsederler.

Rouleau ve Balogun (2011) çalışmalarında özellikle stratejik değişime atıfta bulunarak orta düzey yöneticilerin rollerini nasıl yerine getirdiklerini, bir örgütün gelişimine stratejik olarak nasıl katkıda bulunduklarını ortaya koymuşlardır. Formal olarak stratejik hareket etme yetkisine sahip olmayan orta düzey yöneticilerin kendilerinden istenildiğinde veya informal olarak ihtiyaç duyulduğunda stratejik bir rol üstlenerek örgüte stratejik katkı sağlayabilmek için söylemsel becerilerin önemine vurgu yapar. Bir başka ifade ile bu çalışma orta düzey yöneticilerin stratejik rolleri ve söylemsel yeteneklerini keşfederek değişimle ilgili görevlerde nasıl katkı sağladıkları üzerinedir. Yazar özellikle dil kullanımına ve çoklu paydaş etkileşimine vurgu yapar.

Currie ve Procter'a göre (2005) orta düzey yöneticiler kurumsal stratejiyi eylem planlarına ve bireysel hedeflere dönüştürmek suretiyle strateji uygulamakla görevlidirler. Bu tanımdan yola çıkarak örgütün tepesinden ziyade orta düzey yönetim/yöneticinin örgütsel performansı önemli ölçüde etkilediğini ileri süren literatüre katkı bulunurlar. Orta düzey yöneticilerin rollerine ilişkin çelişkili beklentilerin bir sonucu olarak rol 
çatışması ve rol belirsizliğinin altını çizerler. Orta düzey yöneticilerin örgütün stratejik bağlamını daha iyi anlamaları, stratejinin belirlenmesi ve uygulanmasına katkı sağlamak gibi rol geçişleriyle bu sorunların üstesinden gelinebileceğini ifade ederler.

Herzig ve Jimmieson (2006) örgütsel değişimde orta düzey yöneticilerin tüm kademedeki çalışanlarla iletişim ve etkileşim halinde olması rol çatışmalarının önüne geçerek belirsizlik yönetiminin başarıyla uygulanmasında çok önemli bir rol oynayabilir. Bunların aksi yönde uygulanması sonucunda yöneticiler değişimin önünde ciddi engeller ortaya koyma kapasitesine sahiptirler.

Wooldridge ve Pappas (2007) orta düzey yöneticilerin strateji geliştirme konusuna etkin bir şekilde katılabilmeleri için, sosyal konumlarını kullanmaları ve farklı stratejik bilgileri kanalize eden bir dizi ağ ilişkilerini geliştirmeleri gerektiğini ifade etmektedir. Çünkü yöneticilerin sosyal bağlantılarının farklı faaliyetleri teşvik ettiğini ve bu durumun örgütün yenilenmesine yardımcı olduğunu savunmaktadırlar.

Floyd ve Wooldridge (2008) stratejik yönetim üzerine yapılan araştırmaların kapsamlı bir incelemesini yapmış ve "strateji sürecine ilişkin literatürün orta düzey yönetim perspektifini desteklemek üzere geliştiğini" ortaya koymuştur. Stratejik rolleri içinde, orta düzey yöneticiler örgütsel stratejiye katkıda bulundukları bir dizi yolu kullanırlar. Bu alanda yapılan çalışmalar, orta düzey yöneticilerin stratejiyi etkilemek için kullandıkları teknikler ve pratiklere odaklanmıştır.

Mair ve Thurner (2008) orta ölçekli işletmelerde orta düzey yöneticilerin rolleri ve uluslararasılaşma stratejisi sürecine katılımları üzerinde durmuş ve orta düzey yöneticilerin proaktif olarak stratejilere dâhil olmalarını, stratejik insiyatiflerin sonuçlarının sahibi olduklarına inanmalarına bağlamıştır. Bu algı, orta düzey yöneticilerin davranışları ve uluslararasılaşmaya karşı tutumlarında belirleyici bir etkiye sahipken, orta düzey yöneticilerin uluslararasılaşmaya yönelik daha fazla fırsat odaklı bir tutum sergilemelerine yol açmaktadır.

Mantere (2008) rol beklentilerinin orta düzey yöneticilerin stratejik rolünü bir yandan etkinleştirirken diğer yandan sınırlama potansiyeline sahip olduğunu vurgular. Ayrıca, örgütsel topluluğun temsilcileri olarak üst yönetim ile orta yönetim arasındaki ilişkinin karşııklı rol beklentileri ile nasıl anlaşılabileceğine dair bilgiler sunmaktadır.

Yang ve ark. (2010) orta düzey yöneticilerin örgütsel hiyerarşi üzerindeki etkisi açısından dönüşümcü liderliği incelemişler ve söz konusu yöneticilerin dönüşümcü liderlik becerilerini kullanmalarının alt düzey çalışan performansı üzerindeki olumlu etkisinden bahsetmişlerdir. Yazarlar öncelikle dönüşümcü liderin tanımından yola çıkarak, gelecek vizyonuna sahip ve bunu takipçilerine (astlarına) resmi olmayan kanallar yoluyla doğrudan aktaran; kendisi de savunulan değerlerle tutarlı bir şekilde hareket ederek onlara iyi bir rol model olan orta düzey yöneticilerin, çalışanlar arasında iş birliğini teşvik ederek ortak bir hedef doğrultusunda birlikte çalışmak için gerekli motivasyonu sağlayacağından bahseder. Dönüşümcü lider bir yandan mükemmellik, kalite ve üstün performans konusunda ısrar ederek bu konudaki beklentilerini ifade ederken diğer yandan takipçilerin kişisel duygu ve ihtiyaçlarına özen gösterir ve takipçilerine çalışmalarıyla ilgili bazı varsayımlarını tekrar gözden geçirmek ve çalışmalarını nasıl daha iyi gerçekleştirilebileceğiyle ilgili yeniden düşünmesi için entelektüel teşvik sağlar. Bu nedenle yazarlar dönüşümcü liderlik özelliklerini sergileyen orta düzey yöneticilerin, çalışanların iş performansını olumlu yönde etkilediğini ve bireysel performanslarını organizasyon hedefleriyle ilişkilendirerek örgütsel başarıya olumlu katkı sağladıklarını ifade etmişlerdir.

Hope (2010) planlı değişimin uygulanması sırasında orta düzey yönetimin politik eylemlerini incelemiş ve orta düzey yöneticilerin örgütlerde başkalarının stratejik algılarını etkilemek için farklı politik güçleri kullanabilecek konumda olduklarını tespit etmiştir.

Shirey (2011) özellikle örgütsel değişim kavramına vurgu yaparak çalışan katılımının, stratejinin sahiplik duygusunu teşvik ettiği ve örgütsel yetenekleri geliştirdiğini ileri sürmektedir.

Salih ve Doll (2013) strateji uygulamalarını etkileyen örgütsel faktörler üzerine orta düzey yöneticilerin görüşlerini almıştır. On iki orta düzey yönetici ile yapılan nitel araştırma verilerine dayanarak yürüttükleri bu çalışmada katılımcı yönetim tarzı, stratejik uyum, içsel iletişim ve orta düzey yönetimin katkısının strateji uygulamalarını etkileyen kritik faktörler olduğunu ortaya koymuşlardır. Bu çalışmanın 
literatüre bir diğer katkısı ise, orta düzey yöneticiler açısından strateji uygulama sürecinde karşılaşılan engellere dair bilgi düzeyini artırmaktır.

Meissner ve Radford (2015) hizmet sektöründe (yaşlı bakım kuruluşları) yaptıkları çalışmada orta düzey yöneticilerin yönetsel becerilerinin önemi ve bunun performans üzerindeki etkisini araştırmışlardır. Özellikle hizmet sektöründe teknik becerilerden ziyade söylemsel becerilerin geliştirilmesi gerektiği, bunun sağlanamadığı durumlarda örgütün müşterilerine kaliteli hizmet sunmada yetersiz kalacağı ifade edilmektedir.

Kamu kurumlarında yapılan çalışmalar genellikle orta düzey yöneticilerin uygulamadaki rollerine odaklanırken Chen, Berman ve Wang (2014) yaptıkları çalışmada kamu kurumlarında orta düzey yöneticilerin alternatifleri savunma ve bilgi sentezleme rollerini vurgulayarak literatüre katkıda bulunmaktadır. Yazarlar iş güvenliği, paydaşlarla olan ilişkiler ve motivasyonun orta düzey yöneticilerin alternatifleri belirleme ve bilgiyi sentezleme etkinliklerinin en önemli belirleyicileri olduğunu ifade etmektedirler.

\section{Sonuç}

İçinde yaşadığımız değişken ve belirsiz çevre, örgüt yapılarında, pazarlarda ve iş stratejilerinde önemli değişiklikleri zorunlu kılmaktadır. Geleneksel hiyerarşik yapılar giderek ağ ve proje tabanlı iş formatlarını daha fazla kullanan bilgi yoğun ve esnek örgüt yapılarına evrilmektedir. Orta düzey yöneticilerin bu yeni örgüt düzenine uyum sağlaması söz konusu yönetim kademesinin tanımı ve rolleri üzerine yeniden düşünülmesini gerekli kılmaktadır. Bu çalışmada genel olarak orta düzey yönetim/yöneticiler, hiyerarşik pozisyonları ile strateji belirleme ve uygulama sürecindeki aktif rolleri bakımından literatürde incelenmiştir.

Geleneksel düşünme biçimi orta düzey yönetim/yöneticileri örgüt içerisindeki kontrol kanalları olarak tanımlarken günümüzde birçok rolü yerine getirmesi beklenen yönetici grubu haline gelmiştir. Üst düzey yöneticilere yönelik artan talepler ve belirsizliğin getirdiği baskılar üst düzey yöneticilerin kapasitesini yetersiz hale getirdiğinden, bu durum orta düzey yöneticilerin değerlendirme ve karar alma süreçlerine dâhil olmalarının önünü açmaktadır. Bunun yanı sıra iletişim ve bilgi teknolojilerinde yaşanan değişimler ve bu değişimlerin getirdiği esnek örgüt yapılarının bir sonucu olarak orta düzey yöneticilerin stratejik değerine yönelik görüşlerin arttığı gözlenmektedir. Konumları itibariyle örgütteki her düzeye yakın olan ve her bir düzeyle bilgi alışverişinde bulunarak üst düzey yöneticileri, akranları ve çalışanları doğrudan etkileme potansiyeline sahip olan orta düzey yöneticiler günümüzde değişimlerin ve meydan okumaların önemli kanalları haline gelmektedir. Artık denetçi veya gözlemci olarak değil çalışanlara rehberlik ederek, etkin çalışma ortamları oluşturarak, motivasyon sağlayarak çalışanların gelişimine destek olan bir yönetici profili çizmektedir. Dış çevre ve iç operasyonlar konusunda diğer yönetim düzeylerine göre daha fazla bilgi sahibi olan orta düzey yöneticilerin karar alma süreçlerinde yer alması gerek alınan kararların kalitesinin artması gerekse uygulamadan sorumlu olanların alınan kararın amacını anlamasını kolaylaştırmaktadır. Örgüt çalışanlarının kurum değerlerini anlaması, bu değerlere sahip olma isteğinin sağlanması ve çalışanların örgüt hedeflerine bağlı kalmalarında orta düzey yönetim ve yöneticinin rolü önemlidir. Kurum değerlerini ve amaçlarını eylemleriyle örgütün her biriminde günlük davranışlara dönüştürürler. Üst düzey yöneticilere kıyasla müşterilere ve pazara daha yakın olan orta düzey yöneticiler talepteki değişimleri kısa sürede fark ederek; stratejik girişimleri buna göre değerlendirme ve yönlendirme fırsatına sahiptirler. Tüm bunlar nihayetinde işletmelerde verimlilik artışına yol açmakta ve hizmet ettikleri organizasyonlara uzun vadeli, sürdürülebilir rekabet avantajı kazandırmaktadır. Böylece günümüzde orta düzey yöneticilerin iletişim ve iş birliği gibi geleneksel rollerinin yanında değişim ajanı, girişimci ve hatta stratejik liderlik gibi yeni rolleri ortaya çıkmaktadır. Bu roller örgütün temel yeteneklerinin geliştirilmesi ve sürdürülmesinde önemlidir. Ayrıca örgütün temel yeteneği ile rekabet avantajı bağlantısını kuracak olan da yine orta düzey yöneticilerdir. Bir başka ifade ile yeni bilgilerin oluşturulduğu, oluşturulan bu fikirlerin yöneticiler ve diğer örgütsel aktörler arasında karmaşık sosyal etkileşimlere girdiği, yeteneklerin geliştirildiği bir sosyal öğrenme süreci aracılığıyla yeni stratejilerin ortaya çıktığı ve uygulandığı bu süreçte orta düzey yöneticiler bir organizasyonun rekabetçi pozisyonuna olumlu katkıda bulunmaktadırlar. 


\section{Kaynaklar}

Akyüz, Ö. F. (2006). Değişim rüzgârında stratejik insan kaynakları planlaması. İstanbul: Sistem Yayınları.

Ansari, M., \& Kapoor, A. (1987). Organizational context and upward influence tactics. Organizational Behavior and Human Decision Processes, 40(1), 39-49.

Argyris, C., \& Schön, D. (1978). Organizational learning: A theory of action perspective. Reading, MA: Addison Wesley.

Balogun, J. (2003). From blaming the middle to harnessing its potential: Creating change Intermediaries. British Journal of Management, 14(1), 69-83.

Bingöl, D. (1998). Insan kaynakları yönetimi (4. Baskı). İstanbul: Beta Yayınları.

Boyett, I., \& Currie, G. (2004). Middle managers moulding International strategy: An Irish start-up in Jamaican telecoms. Long Range Planning: International Journal of Strategic Management, 37(1), 51-66.

Bower, G.H. (1970). Imagery as a relational organizer in associative learning. Journal of Verbal Learning and Verbal Behavior, 9, 529-533.

Brower, R. \&, Abolafia, M. Y. (1995). The structural embeddedness of resistance among public managers. Group \& Organization Management, 20(2), 149-166.

Chakravarthy, B. S. (1982). Adaptation: A promising metaphor for strategic management. Academy of Management Review, 7(1), 35-44.

Chen, C. A., Berman, E. M., \& Wang, C. Y. (2014). Middle managers' upward roles in the public sector. Administration \& Society, 49(5), 700-729.

Currie, G., \& Procter, S. J. (2005). The antecedents of middle managers strategic contribution: The case of professional bureaucracy. Journal of Management Studies, 42, 1325-1355.

Daft, R. L. (2000). Organization theory and design (7th Edition). Ohio: South-Western Publishing.

Delmestri, G., \& Walgenbach, P. (2005). Mastering techniques or brokering knowledge? Middle managers in Germany, Great Britain and Italy. Organization Studies, 26(2), 197-220.

Dennis, J-L., Langley, A., \& Rouleau, L. (2005). Rethinking leadership in public organization. In E. Ferlie, Oxford: Oxfors University Press.

Dutton, J. E., \& Ashford, S. J. (1993). Selling issues to top management. The Academy of Management Review, 18(3), 397-428.

Dutton, J. E., \& Jackson, S. E. (1987). Categorizing strategic issues: Links to organizational action. Academy of Management Review, 12, 76-90.

Dutton, J. E., Ashford, S.J., O’Neil, R. M., Hayes, E., \& Wierba, E. E. (1997). Reading the wind: How middle managers assess the context for selling issues to top managers. Strategic Management Journal, 18 (5), 407-425.

Floyd, S. W., \& Wooldridge, B. (1996). The strategic middle manager: How to create and sustain competitive advantage. San Francisco: Jossey-Bass.

Floyd, S. W., \& Wooldridge, B. (1997). Middle management's strategic influence and organizational performance. Journal of Management Studies, 34(3), 465-485.

Floyd, S. W., \& Lane, P. J. (2000). Strategizing throughout the organization: Managing role conflict in strategic renewal. The Academy of Management Review, 25(1), 154-177.

Floyd, S. W., \& Wooldridge, B. (2000). Building strategy from the middle: Reconceptualizing strategy process. Thousand Oaks: Sage Publications.

Glauser, J. M. (1984). Upward information flow in organizations: Review and conceptual analysis. Human Relations, 37(8).

Griffin, A. (1997). Modeling and measuring product development cycle time across industries. Journal of Engineering and Technology Management, 14 (1), 1-24.

Guth, D. W., \& MacMillan, I.C. (1986). Strategy implementation versus middle management self-interest. Strategic Management Journal, 7(4), 313-327.

Hancock, N., \& Hellawell, D. (2003). Academic middle management in higher education: A game of hide and seek. Journal of Higher Education Policy and Management, 1(25), 4-13.

Harari, E., \& Zeira, Y. (1977). Third-country managers in multinational corporations. Personnel Review, 6(1), 32-37.

Herzig, S. E., \& Jimmieson, N. L. (2006). Middle managers' uncertainty management during organizational change. Leadership \& Organization Development Journal, 27(8), 628-645. 
Heyden, M. L. M., Fourné, S. P. L., Koene, B. A. S., Werkman, R., \& Ansari, S. M. (2017). Rethinking 'top-down' and 'bottom-up' roles of top and middle managers in organizational change: Implications for employee support. Journal of Management Studies, 54(7), 961-985.

Hrebiniak, L. G., \& Joyce, W. F. (1984). Implementing strategy. New York: MacMillan Publishing Company.

Hope, O. (2010). The politics of middle management sensemaking and sensegiving. Journal of Change Management, 10(2), 195-215.

Jackson, D., \& Humble, J. (1994). Middle managers: New purpose, new directions. Journal of Management Development, $13(3), 15-21$.

Jarzabkowski, P., \& Balogun, J. (2009). The practice and process of delivering integration through strategic planning. Journal of Management Studies, 46(8), 1255-1288.

Joseph, E. E., \& Bruce, W. (2005). A correlation of servant leadership, leader trust, and organizational trust. Leadership \& Organization Development Journal, 26(1), 6-22.

Judge, W. Q., \& Stahl, M. J. (1995). Middle-manager effort in strategy implementation: A multinational perspective. International Business Review, 4(1), 91-111.

Kanter, R. M. (1982). The middle manager as innovator. Harvard Business Review, 60(4), 95-105.

Kanter, R. M. (1983). The change masters: Innovations for productivity in the American Corporation. University of Illinois at Urbana-Champaign's Academy for Entrepreneurial Leadership Historical Research Reference in Entrepreneurship.

King, A. W., Fowler, S. W., \& Zeithaml, C. P. (2001). Managing organizational competencies for competitive advantage: The middle management edge. The Academy of Management Executive, 15(2), 95-106.

Koçel, T. (2011). Iş̧letme Yöneticiliği. İstanbul: Beta Basım Yayım Dağıtım.

Likert, R. (1961). New patterns of management. New York: McGraw-Hill.

Mair, J. (2005). Exploring the determinants of unit performancethe role of middle managers in stimulating profit growth. Group \& Organization Management, 30(3), 263-288.

Mair, J., \& Thurner, C. (2008). Going global: How middle managers approach the process in medium-sized firms. Strategic Change, 17(3-4), 83-99.

Mantere, S. (2008). Role expectations and middle manager strategic agency. Journal of Management Studies, 45(2), 294-316

Martin, J. A., \& Eisenhardt, K. M. (2010). Rewiring: Cross-business-unit collaborations in multibusiness organizations. The Academy of Management Journal, 53(2), 265-301.

McConville, T., \& Holden, L. (1999). The filling in the sandwich: HRM and middle managers in the health sector. Personnel Review, 28(5/6), 406-424.

Meissner, E., \& Katrina, R. (2015). Importance and performance of managerial skills in the Australian aged care sector A middle managers' perspective. Journal of Nursing Management, 23, 784-793.

Mintzberg, H. (1979). The Structuring of organizations. Englewood Cliffs NJ: Prentice Hall.

Nemeth, C.(1997). Managing innovation: When less is more. California Management Review. 40(1), 58-74.

Nonaka, I. (1988). Toward middle-up-down management: Accelerating information creation. Sloan Management Review, 29(3), 9-18.

Nonaka, I. (1994). A dynamic theory of organizational knowledge creation. Organization Science, 5(1), $14-37$.

Nonaka, I., \& Takeuchi, H. (1995). The knowledge-creating company: How Japanese companies createthe dynamics of innovation. New York: Oxford University Press.

Nutt, P. C. (1987). Identifying and appraising how managers install strategy. Strategy Management Journal, 8(1), 1-14.

O'Shannassy, T. (2013). Modern strategic management: Balancing strategic thinking and strategic planning for internal and external stakeholders. Singapore Management Review, 25(1), 53-67.

Ranson, S., Hinings H. R. \& Greenwood, R. (1980). The structure of organizational structures. Administrative Science Quarterly, 25(1), 1-17.

Rezvani, Z. (2017). Who is a middle manager: A literature review. Journal of Family Business Management, 1(2), 1-9.

Rouleau, L. (2005). Micro-practices of strategic sensemaking and sensegiving: How middle managers interpret and sell change every day. Journal of Managament Studies, 42(7), 1413-1441). 
Rouleau, L., \& Balogun, J. (2011). Middle managers, strategic sensemaking, and discursive competence. Journal of Management Studies, 48(5), 953-983.

Salih, A., \& Doll, Y. (2013). A middle management perspective on strategy implementation. International Journal of Business and Management, 8(22), 32-39.

Schilit, W. K. (1987) An examination of the influence of middle-level managers in formulating and implementıng strategic decisions. Journal of Management Studies, 24(13), 271-293.

Schilit, W. K., \& Locke, E. A. (1982). A Study of upward influence in organizations. Administrative Science Quarterly, 27(2), 304-316.

Sharyn, E. H., \& Jimmieson, N. L. (2006). Middle managers' uncertainty management during organizational change. Leadership \& Organization Development Journal, 27(8), 628-645.

Shirey, M. R. (2011). Addressing strategy execution challenges to lead sustainable change, strategic leadership for organizational change. The Journal of Nursing Administration, 41(1), 1-4.

Song, S., \& Olshfski, D. (2008). Friends at work: A comparative study of work attitudes in Seoul City Government and New Jersey State Government. Administration and Society, 40(2), 147-169.

Stoner, J. A. F., \& Freeman, R. E. (1992). Management (Fifth Edition). London: Prentice Hall International.

Tezcan, M. (1980). Toplumsal değişimlerin ülkemiz eğitimine etkileri. Eğitim ve Bilim Dergisi, 5(25).

Tregoe, B. B., \& Tobia, P. M. (1990). An action-oriented approach to strategy. Journal of Business Strategy, 11(1), $16-21$.

Wooldridge, B., \& Pappas, J. M. (2007). Middle managers' divergent strategic activity: An investigation of multiple measures of network centrality. Journal of Management Studıes, 44(3), 323-341.

Wooldridge, B., \& Floyd, S. (1990). The strategy process, middle management and organizational performance. Strategic Management Journal, 11(3), 231-241.

Wooldridge, B., \& Floyd, S. W. (1992). Middle management involvement in strategy and its association with strategic type: A research note. Strategic Management Journal, 13(1), 153-167.

Wooldridge, B., Schmidt, T., \& Floyd, S. (2008). The middle management perspective on strategy process: Contributions, synthesis, and future research. Journal of Management, 34(6), 1190-1221.

Yang, J., Zhang, Z., \& Tsui, A. S. (2010). Middle manager leadership and frontline employee performance: Bypass, cascading, and moderating effects. Journal of Management Studies, 47(4), 654-678.

Westley, F. R. (1990). Middle managers and strategy: Microdynamics of inclusion. Strategic Management Journal, 11(5), 337-351. 